\title{
Lektioita
}

\author{
Eeva-Lotta Apajalahtia
}

\section{Large energy companies in transition - From gatekeepers to bridge builders}

\author{
Lectio Praecursoria \\ Aalto University, 8.6.2018
}

\section{Part I:The journey}

For the past ten years, I have been privileged to be able to follow the ever interesting energy field and the changes that are taking place. I studied the energy field through the eyes of two of the largest energy companies in Finland: Helen, the largest municipal energy company and Fortum, a large internationally operating company.

During these years, the energy field have changed. The changes have been equalled in significance to the transformation in the early 20th century, when electricity was widely introduced to societies. Today, we have more renewable energy than ever before, energy markets are operating in a competitive environment and investments in renewable energy has been increasing. The contemporary changes are driven by the rising awareness of the climate change, which is, by now, incorporated into various policy initiatives and long-term strategic visions of organisations, municipalities and cities.

Climate change has also become one of the key drivers of innovation within the energy field. In order to reduce $\mathrm{CO} 2$ emissions and due to the increasing cost effectiveness of renewable energy technologies, the world has seen an increasing number of renewable energy capacity installations. According to Frankfurt School-UNEP Collaborating Centre (2017) renewable investments almost doubled in 2016 compared to investments in traditional fossil fuel generation globally.

It is justified to argue that the significance of large energy companies in advancing renewable energy has increased. To test this, I would challenge any one of you to go to the webpage of your own energy provider. Look for a contract model that enables you to purchase only renewable energy. If you cannot find that already on the first page, then surely at least when you look at the selection of the contract models. This was not the case only five years ago.

These changes are a part of a so-called energy transition. Transition is a long-term sociotechnical change, which means that the development and use of certain technologies are tightly entangled with the social processes. - for example where the technology is developed and used, who are the developers, what political processes are involved and so forth.

The long-term refers to a time period of some 50-60 years. One of the most used historical

${ }^{a}$ Helsingin yliopisto, eeva-lotta.apajalahti@helsinki.fi 
case studies is the shift from using horse-driven carriages to cars. That example captures well the nature of transition.

I consider myself as a transition scholar, and with my dissertation, I am contributing to this fairly new field of sustainable transition studies. Sustainability transitions can be defined as a "long-term, multi-dimensional, and fundamental transformation processes through which established socio-technical systems shift to more sustainable modes of production and consumption", following Markard, Raven and Truffer (2012).

Although the rapid diffusion of renewable energy implies that the energy field is going through a rapid transformation, the contemporary energy system is still largely controlled by large energy companies, which dominate the production, organisation and distribution of energy in modern societies. It would be unfair to claim that we have reached renewable energy system. Global energy production is still largely dominated by fossil fuels (2016): oil 32 percent, coal 27 per cent and natural gas 22 per cent (IEA 2018). A lot needs to be done and we need all the actors on board.

\section{Part II:The story}

My dissertation tells a story of how the past ten years has looked like through the eyes of two large energy companies. This means that I have tried to picture and understand how people in large energy companies perceive the transition, how they interpret what they do and how they make decisions to comply with the increasing societal, political, technological and economic pressures to tackle the challenge of climate change. Next, I will walk you through the story of a large energy company that is going through the energy system change.

My research reaches back to the very first steps of the largest municipal energy company, Helsingin Energia, now known as Helen, a hundred and ten years ago. I have studied the history of Helen in the first dissertation essay. This essay forms the backbone of the whole thesis, forming a historical path and a continuum from the early days of electricity provision for everyday life in the City of Helsinki, to the recent years of turbulence and a return to the idea of decentralised energy generation - the very system that the currently dominant large-scale centralised system was developed to replace. This first study has been a kind of a companion during the whole thesis process and it has been 'living' on the way, especially in the past few years, in which the situation in Helsinki has changed.

Although large energy firms have started to develop and invest in new business and renewable energy, letting go of the old operating modes is not easy. The technological investments made in the past, technological interlinkages, learning effects and coordination effects have created a strong carbon and technology dependency. Helen's carbon and technology dependency is based on the extremely efficient large-scale combined heat and power production, and its linkage with affordable fossil fuels that have high energy content. Moreover, the historically close relationship with the city and city's energy needs has strengthened the dependency.

Breaking away from this dependency is difficult but not impossible. Helen's case shows how gradually increasing and continuous pressures for change have opened up possibilities for breakout of the dependency. The same processes, so called self-reinforcing processes, which led to the dependency and sustains it, have started to weaken. For example, the technological interlinkage of combined heat and power production, so called CHP, and district heating network have started to loosen. New renewable energy solutions challenge either the heat production, such as heat pumps, or the electricity production. Furthermore, the low electricity prices are eating up the profitability of CHP. Also the linkage with the city have changed. I consider the city council's decision to close down Hanasaari before the end of its operating lifecycle as an indicator of a break-out.

The decision was not easy as city representatives postponed it several times before reaching the final decision in 2015. The three of the largest change pressures have been, first, the pressure to reduce coal use and carbon dioxide emissions; second, the slowly increasing challenges of profitability of combined heat and power production, and third, slightly surprising but almost 
as significant as reducing coal use, has been the debate over city space usage. Helsinki has been planning for years to construct residential and office buildings in Hanasaari, the location of Helen's large coal power plant. Constructing nearby metro station and Kalasatama residential area as well as shifting the harbour outside the city centre from kalasatama, have all been part of this plan.

The pressure to reduce coal use will increase in the near future, because Finland's government just made a decision to ban the use of coal by 2029. Therefore, it is not only about the destiny of the Hanasaari power plant, but also the power plant in Salmisaari, which will be a topic for the following years to come.

The second essay takes place in the time period after energy market liberalisation, which can be considered as 'turning pains' for the municipal energy utility; becoming a market-oriented, profit-seeking company that shifted away from its monopoly position as a producer of public goods. It is a story of coping with different expectations and 'conflicting institutional demands'. These demands, ranging from the EU directive on energy end use saving and efficiency, national policy and energy end-users' perspectives, demonstrate the challenges associated with developing a more sustainable electricity contract model.

The organisation faced great difficulties in developing its energy saving business model for two main reasons. First, the unbundling of business operations, which was an outcome of energy market liberalisation, had created strong boundaries between different operative business units. Developing a model would have required different units to work together. The development of this model was hindered by the lack of communication channels, a common development platform and a common budget for developing such a model.

Second, the organisation faced considerable distrust from its customers over the energy company's motivations to develop a contract model that would save energy: "energy companies are privately owned listed companies, why would they want to save energy, the very product that they get profit from?" Customers had internalised the new market-based operating culture of energy companies, which produced the idea that energy companies offering energy-saving contract models to their customers is self-contradictory.

The third essay is a result of diving into the unexpected. I used researcher's freedom to follow something surprising. After having studied the challenges encountered in the development of the energy saving contract model and after looking into path dependencies, and possible path break-out, I was surprised by the announcements of Helen and Fortum to launch solar panel packages to households.

During the time period of the third study, Helen constructed two large solar power plants in Finland, and Fortum started to advocate a shift towards a 'Solar Economy by 2050'. Fortum also set up a solar programme in India. Thus the third study tells the story of a successful business development and the interpretation of how this influenced the two technological fields of solar energy and electric vehicles charging business. This latest twist convinced me that the energy field in Finland is, indeed, under reorientation and new energy solutions are increasingly being introduced. These latest twists complement my first essay and form a kind of a closure to the 110-year history of energy entering to the City of Helsinki.

What can I conclude based on my research? It is highly likely that in the energy field, many of today's large energy companies will persist and dominate in some form for decades yet to come - because of the locus of power, positions, resources and energy infrastructure changes slowly. Such viewpoints suggest that large energy companies would be expected to be in the forefront of the shift towards a more sustainable energy system, if we are to shift to more sustainable system.

Some might claim that my take on the activities of large energy companies is a friendly one towards large energy companies. My concern, and the main motivation to study large energy companies is that we have had too little focus on them. We cannot afford to not to study these actors because they are in a crucial position for taking energy transition forward. The wider implications of large energy companies' entrance in renewable energy fields need further qualification. 


\section{Part III:The continuity}

I do acknowledge that large energy companies are struggling with the transition. And many of the struggles occur within the energy companies. There is still a lot of resistance to change. Therefore, more studies are needed on the energy companies' organisational structures, which keep these large players attached to the mainstream ways of producing energy. Transition is not something that occurs on its own but it needs to be actively pushed forward. The quest is not just for strategic choices for developing new business solutions but also about 'unlearning' and 'letting go'.

More positive examples are needed of how energy companies' involvement in renewable energy affects these new energy fields. Moving away from labelling these actors as hijackers of transition, this study works towards an understanding of how, by engaging in renewable energy and new technologies, large energy companies come to develop solutions that are a bridge between mainstream markets and more sustainable ways of producing energy: thus working as a bridge builders of transition.

The seeds of transition are sown within the studied energy companies. Yet, it is true that the change is slow. We wouldn't have any time to spare. However, during the past ten years, I have seen new paths emerging within the studied companies. After all, there seems to be hope for the transition to speed-up its pace. In order to achieve that, we need large energy companies to be on the move.

\section{References}

Frankfurt School-UNEP Centre/BNEF (2017) Global trends in renewable energy investment 2017. <http://www. greengrowthknowledge.org/resource/global-trends-renewable-energy-investment-2017>

IEA (2018) Key World Energy Statistics 2018 < https://webstore.iea.org/key-world-energy-statistics-2018> 21.5.2019

Markard, J., Raven, R. \& Truffer, B. (2012) Sustainability transitions: An emerging field of research and its prospects. Research Policy 41(6) 955- 967. <https://doi.org/10.1016/j.respol.2012.02.013>

\section{Väitöskirjan tiedot}

Eeva-Lotta Apajalahti: Large energy companies in transition - From gatekeepers to bridge builders. Aalto University publication series Doctoral Dissertations, 112/2018. ISBN 978-95260-8033-8 ISSN 1799-4942. Aalto University School of Business, Helsinki 2018.

Saatavilla osoitteesta: http://urn.fi/URN:ISBN:978-952-337-140-8 